\title{
Mutations in the gene of the Ga subunit of the heterotrimeric $G$ protein are the cause for the brachytic1 semi-dwarf phenotype in barley and applicable for practical breeding
}

Ilka Braumann ${ }^{1}$, Christoph Dockter ${ }^{1}$, Sebastian Beier ${ }^{2}$, Axel Himmelbach², Finn Lok ${ }^{1}$, Udda Lundqvist ${ }^{3}$, Birgitte Skadhauge ${ }^{1}$, Nils Stein ${ }^{2}$, Shakhira Zakhrabekova ${ }^{4}$, Ruonan Zhou ${ }^{2}$ and Mats Hansson ${ }^{4^{*}}$ (D)

\begin{abstract}
Background: Short-culm mutants have been widely used in breeding programs to increase lodging resistance. In barley (Hordeum vulgare L.), several hundreds of short-culm mutants have been isolated over the years. The objective of the present study was to identify the Brachyticl (Brh1) semi-dwarfing gene and to test its effect on yield and malting quality.

Results: Double-haploid lines generated through a cross between a brh1.a mutant and the European elite malting cultivar Quench, showed good malting quality but a decrease in yield. Especially the activities of the starch degrading enzymes $\beta$-amylase and free limit dextrinase were high. A syntenic approach comparing markers in barley to those in rice (Oryza sativa L.), sorghum (Sorghum bicolor Moench) and brachypodium (Brachypodium distachyon P. Beauv) helped us to identify Brh1 as an orthologue of rice D1 encoding the Ga subunit of a heterotrimeric G protein. We demonstrated that Brh1 is allelic to Ari-m. Sixteen different mutant alleles were described at the DNA level.

Conclusions: Mutants in the Brhl locus are deficient in the Ga subunit of a heterotrimeric G protein, which shows that heterotrimeric $\mathrm{G}$ proteins are important regulators of culm length in barley. Mutant alleles do not have any major negative effects on malting quality.
\end{abstract}

Keywords: Ari-i, Ari-m, Brh1, Hordeum vulgare, Semi-dwarf

\section{Background}

Semi-dwarfism is regarded as a valuable trait in cereal breeding, as cultivars with a short stature show increased lodging resistance [6, 25]. Due to the potential agronomic usefulness, many different types of semidwarf mutants have been identified in barley (Hordeum vulgare) during the last 70 years. These semi-dwarf mutants have obtained different names since they often have other pleiotropic characters which might have been in focus of the involved research group. The major semidwarf subgroups are Brachytic (Brh), Breviaristatum (Ari), Slender dwarf (Sld), Erectoides (Ert), Semidwarf (Sdw), Semi-brachytic (Uzu) and Dense spike (Dsp) [10]. However, only a few barley semi-dwarfing genes have

\footnotetext{
* Correspondence: mats.hansson@biol.lu.se

${ }^{4}$ Department of Biology, Lund University, Sölvegatan 35, SE-22362 Lund, Sweden

Full list of author information is available at the end of the article
}

successfully been applied in breeding programs - The uzu1.a allele was one of the first short-culm alleles to be used [31] and has been introduced in almost all Japanese hull-less barley cultivars [26]; two different alleles of the Semidwarf 1 gene, sdw1.c (originally named denso) and $s d w 1 . d$, are most likely the dominating short-culm alleles in the today's European elite cultivars [10]; ert-k.32 was isolated after X-ray treatment in the cultivar Bonus and released as the cultivar Pallas [13]; ari-e.GP was isolated after $\gamma$-ray mutagenesis of cultivar Maythorpe in 1956 and released as Golden Promise [1, 12]; sdw4.ba was isolated after $\gamma$-ray treatment of the Chinese cultivar Zhenongguangmangerleng in the late $1960 \mathrm{~s}$ and is now probably widespread in many semi-dwarf barley accessions in China through the cultivar released as Zhepi 1 [37, 38]. 
Plant hormones like gibberellic acid (GA) and brassinosteroids (BR) are the major regulators of plant height. It is therefore not surprising that successful "Green revolution" semi-dwarfing genes can be exemplified by Reduced height1 (Rht1) in wheat encoding a transcriptional regulator with a DELLA domain involved in GA signaling [23], Semi-dwarf1 $(S d 1)$ in rice $[3,28]$ and $S d w 1$ in barley [36] both deficient in a gibberellin 20-oxidase of the GA biosynthetic pathway, and $U z u 1$ in barley encoding the brassinosteroid receptor [7, 9].

An interesting mutant, not only in the context of plant breeding but also for identification of genetic factors determining plant height, is brachytic1 (brh1), which was originally identified after a spontaneous mutation event in the barley cultivar Himalaya [24, 30]. Outgrown plants have an upright gross morphology with short leaves, culms, spikes, awns and kernels, and their seedling leaf is reduced in length (Fig. 1). The mutant phenotype is easy to classify at all stages of growth (www.nordgen.org/bgs). In total, ten recessive brh1 alleles have been isolated in a wide range of different genetic backgrounds. One allele was previously classified as ari-i but shown to be allelic to brh1 through diallelic crosses [33] (Table 1). Brh1 was mapped to chromosome $7 \mathrm{HS}$ and is inherited in a monofactorial recessive manner [24, 30]. Eight of the ten brh1 alleles are further available as near-isogenic lines through recurrent backcrosses to the two-row spring barley cultivar Bowman (Table 1) [11]. Trait analysis of brh1 mutants in the genetic background of Bowman showed that several brh1 alleles reduce lodging without causing significant yield reduction [8]. In addition, the globe-shaped form of brh1 mutant seeds could also be of potential value; such seed form is generally preferred by maltsters as it is associated with an even germination in the malt house. However, the overall effect of $b r h 1$ mutations on malting is currently unknown. Still, when elucidating if brh1 alleles could indeed serve as an alternative dwarfing gene in barley, it is of particular importance to exclude a negative impact of the mutation on malting quality.

The aim of the present study was to identify the Brh1 semi-dwarfing gene and to test its effect on yield and malting quality. We show that Brh1 encodes a subunit of a heterotrimeric $\mathrm{G}$ protein and mutant alleles of Brh1 do not have any major negative effects on malting quality. Heterotrimeric $G$ proteins transfer signals from receptors (G-protein-coupled receptors) to downstream enzymes (effectors) in signaling cascades [32]. The heterotrimeric $G$ protein complex consists of one $G \alpha$, one $G \beta$ and one $G \gamma$ subunit. Brh1 encodes a $G \alpha$ subunit. This is especially interesting in the view that it was recently shown that barley Ari-e encodes a $\mathrm{G \gamma}$ subunit [35], being orthologous to $D E P 1$ in rice [16]. In addition, barley Brh2 encodes a U-box E3 ubiquitin ligase, orthologous to TUD1 in rice (Braumann et al. unpublished). TUD1 has been suggested to physically interact with the $G \alpha$ subunit in rice [15]. Thus, within a short period of time, heterotrimeric G proteins have been identified as a key regulator of plant architecture in barley.

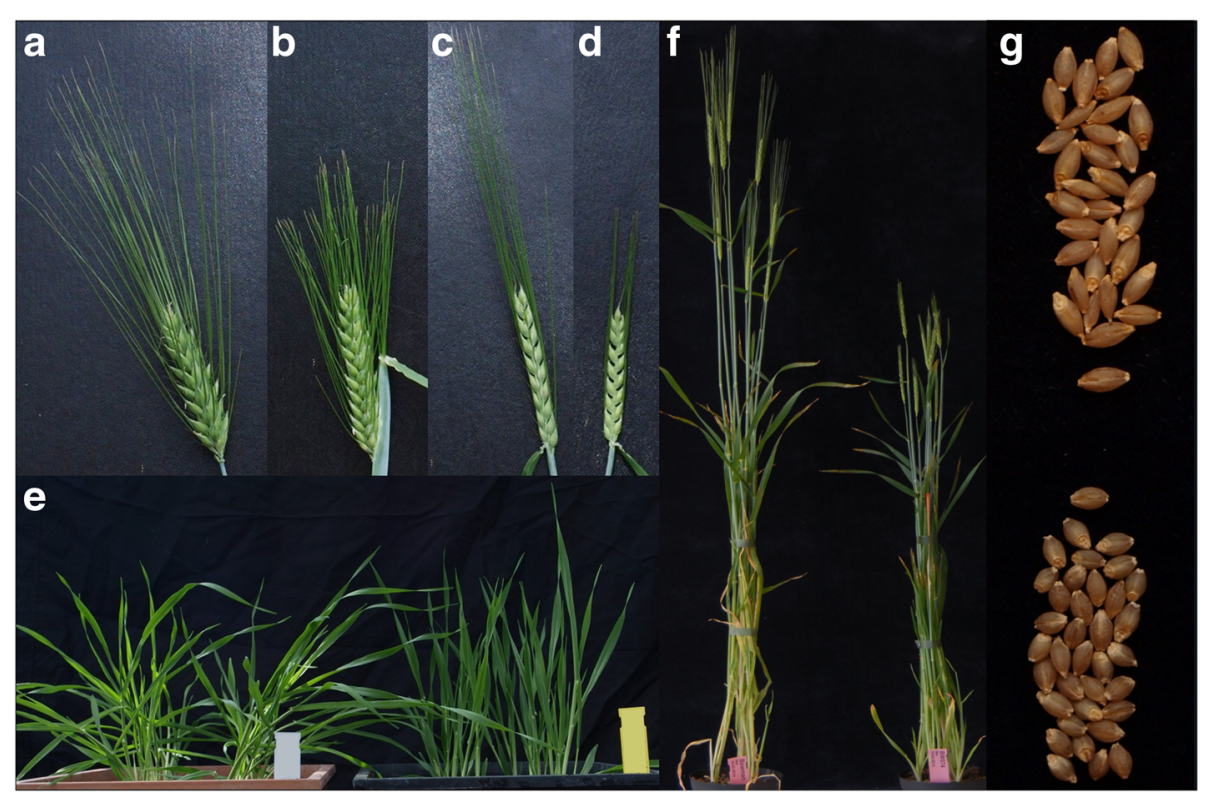

Fig. 1 Phenotype of brh1 mutants in barley compared to the respective mother cultivar. (a) Awn length of cultivar Steptoe, (b) brh1.ae, (c) cultivar Bowman, and (d) near-isogenic line BW074 (brh1.a). e. The erectness of seedlings of cultivar Bowman (left) and BW074 (brh1.a). f. Overall size of Bowman and BW074 (brh1.a) after heading. g. Global-shaped kernels of brh1.a (bottom) compared to cultivar Himalaya (top) 
Table 1 Known brh1 mutant alleles, their genetic background, their availability as Bowman near-isogenic lines, and introgression regions on chromosome $7 \mathrm{H}$

\begin{tabular}{|c|c|c|c|}
\hline Allele & $\begin{array}{l}\text { Genetic } \\
\text { background }\end{array}$ & $\begin{array}{l}\text { Bowman near- } \\
\text { isogenic line }\end{array}$ & $\begin{array}{l}\text { Introgression } \\
\text { region on } \\
7 \mathrm{HS}(\mathrm{cM})\end{array}$ \\
\hline ari-i.38b & Bonus & BW047 & $0-13.19$ \\
\hline$b r h 1 . a^{\mathrm{a}}$ & Himalaya & BW074 ${ }^{\mathrm{b}}$ & $0-13.19$ \\
\hline brh1.aa & Aapo & BW075 & $0-48.45$ \\
\hline brh1.ae & Steptoe & BW076 ${ }^{\mathrm{b}}$ & $0-20.56$ \\
\hline $\operatorname{brh1} . c^{a}$ & Moravian & no line & - \\
\hline brh1.e $e^{a}$ & Aramir & BW077 ${ }^{\mathrm{b}}$ & $0-13.19$ \\
\hline brh1.fa & Domen & no line & - \\
\hline brhi.t. & Akashinriki & BW078 ${ }^{b}$ & $8.77-26$ \\
\hline $\operatorname{brh1} x^{\mathrm{a}}$ & Volla & BW079 & $0-8.77$ \\
\hline $\operatorname{brh1.z^{\mathrm {d}}}$ & Aаро & BW080 ${ }^{b}$ & $0-32.35$ \\
\hline
\end{tabular}

The near-isogenic lines have been prepared previously as well as the determination of the introgressions [11]

Source of seed material: ${ }^{a}$ NSGC, National Small Grains Collection, U.S. Department of Agriculture - Agricultural Research Service, Aberdeen, Idaho, USA; ${ }^{\mathrm{b}}$ Nordic Genetic Resource Center, Alnarp, Sweden; ' Andris Kleinhofs, Washington State University, Pullman, WA, USA; ${ }^{\mathrm{d}}$ not available

\section{Methods}

\section{Plant material}

All mutant lines were obtained from public non-profit organizations or individual contributors: brh1.a, brh1.e, brh1.t, brh1.x, brh1.c and brh1.f from the National Small Grains Collection (U.S. Department of Agriculture Agricultural Research Service, Aberdeen, Idaho, USA); brh1.ae from Andris Kleinhofs, (Washington State University, Pullman, WA, USA); ari-i.38 and the eight Bowman near-isogenic lines BW047 (ari-i.38), BW074 (brh1a), BW075 (brh1.aa), BW076 (brh1.ae), BW077 (brh1.e), BW078 (brh1.t), BW079 (brh1.x) and BW080 (brh1.z) from the Nordic Genetic Resource Center (NordGen, Alnarp, Sweden).

\section{Phenotypic description of mutant and wild type lines}

For phenotypic descriptions, plants were grown in the greenhouse under 16-h-light / 8-h-dark cycles. The culm length measured is the distance between the soil and the collar of the spike. Further, the distances from the collar of the spike to the tip of the spike and to the tip of the longest awn was measured. Awn length was normalized to the length of the spike by forming the ratio of [length from spike collar to tip of longest awn] / [length from spike collar to tip of spike]. Per line 12 plants were grown in large square formed pots. The significance of differences in culm length and awn length between mutant lines and respective wild types was tested by a two sided t-test for two independent populations with equal variance assumption in Microsoft Excel. The number of biological replicates was $n=3$ (in the case of BW047) to $n=12$ depending on the number of seeds that germinated per line.

\section{Generation of double-haploid plants}

In order to transfer brh1.a into a more modern genetic background we performed crosses between the Bowman near-isogenic line BW074 (brh1.a) and the European elite malting cultivar Quench. $F_{1}$ seeds were subjected to embryo rescue 25 days after fertilization. The outer parts of the husk of the developing grains were removed and the grains were sterilized in $4 \%$ sodium hypochlorite for 10 min followed by rinsing in sterile water. The embryos were put onto BAP medium $[0.44 \%(w / v)$ MS powder (Sigma M5524), 0.075\% ( $w / v)$ glutamine, 6\% maltose $(w /$ $v), 1 \mu \mathrm{g} / \mathrm{ml}$ BAP (Sigma B9394) and 0.35\% phytagel ( $w /$ v), pH 5.8]. After 6 weeks, the developing $F_{1}$ plants were transferred to soil. Anthers from undeveloped spikes were transferred into a $0.7 \mathrm{M}$ mannitol solution in petri dishes and incubated for 3 days at $24{ }^{\circ} \mathrm{C}$. Then the anthers were transferred on BAP medium and incubated at $24{ }^{\circ} \mathrm{C}$ for 8 weeks in darkness. Developing calluses were transferred into containers containing MS sucrose medium $(0.22 \%(w / v)$ MS, $1.5 \%(w / v)$ sucrose) and exposed to light for several days. Regenerating plants that turned green were planted into soil and left for seed formation in the greenhouse.

\section{Field tests}

Field testing was done on the Danish island of Fyn during summers 2013 and 2014 using standard nitrogen fertilizer application for malting barley in plots of $7.5 \mathrm{~m}^{2}$ in size. 3600 grains were sown per experimental plot. All lines were tested in triplicates in randomized plots. The experimental plots were harvested using a combiner. The seeds were cleaned prior to weighing and the fraction above $2.2 \mathrm{~mm}$ was kept. The significance of differences in grain yield per plot was tested by a two sided t-test for two independent populations with equal variance assumption in Microsoft Excel.

\section{Germination test}

All barley samples used in the manual malting experiments were evaluated for the parameters Germination index, Germination energy and Water sensitivity. Data was based on a sample size of 100 barley grains for a $4 \mathrm{ml}$ or $8 \mathrm{ml}$ germination test according to Analytica-EBC Method 3.6.2 (http:// analytica-ebc.com/index.php?mod=contents\&scat=10).

\section{Characterization of barley samples}

Thousand kernel weights were determined by automatic counting using a Data Count JR (Data Technologies, Israel). Size fractionation within four classes $(X>2.8 \mathrm{~mm})$, $(2.8 \mathrm{~mm}<\mathrm{X}>2.5 \mathrm{~mm}),(2.5 \mathrm{~mm}<\mathrm{X}>2.2 \mathrm{~mm})$ and $(\mathrm{X}<2.2 \mathrm{~mm})$ was done using a Pfeuffer Sortimat K3 
(Pfeuffer GmbH, Germany). Size fractionation data was calculated from a $100 \mathrm{~g}$ sample. Protein, water and starch content of the barley samples were determined using a near infrared transmittance Foss 1241 NIT instrument (Foss, Denmark) and barley calibration Foss BY213271 provided by the manufacturer. $24 \mathrm{~h}$ prior to micro malting, the water content of the $100 \mathrm{~g}$ sample was re-determined using the same Foss 1241 NIT instrument but barley calibration Foss BY303300. All samples tested in micro malting experiments in this study were grown in rows in New Zealand from September 2012 to February 2013.

\section{Manual micro malting}

All samples were malted using a manual micro malting system developed in house at the Carlsberg Research Laboratory. The micro malting was performed in a Termaks incubator KB8400 (Termaks AS, Norway) at $13.5{ }^{\circ} \mathrm{C}$ during the steeping and germination phase. The barley was malted in individual sample cups each holding $100 \mathrm{~g}$ of barley seeds. One batch of seeds was malted per line. The barley samples were steeped as a forced submission of all grains in a closed sample grid chamber for $3 \mathrm{~h}$. The steeping procedure was performed in three $24 \mathrm{~h}$ intervals. Time recording started when grains were immersed in water first time and set to $0 \mathrm{~h}$. The second steeping period started after $24 \mathrm{~h}$ and third after $48 \mathrm{~h}$. The actual water uptake of the individual barley samples was estimated after a centrifugal removal of water from the sample. Steeping degree was calculated in relation to dry matter of the sample using a Foss 1241 NIT instrument (Foss A/S, Denmark) for determination of dry matter compared to the total sample weight of the sample after centrifugation. Near infrared transmittance is a non-destructive seed analysis, whereby a given chemical compound is assigned to a specific wavelength between $900-1050 \mathrm{~nm}$. Based on a calibration of the instrument it is then possible predict the concentration of that given compound. Following the last steep the barley samples were maintained at a steeping degree at approximately $45 \%$ during the germination step. After the germination process the barley samples were kiln dried in the Termaks incubator for $21 \mathrm{~h}$. The temperature profile of the kiln process was a two-step ramping profile and an isothermal terminal step monitored by a Eurotherm 815 control unit (Eurotherm by Schneider Electric, USA). First ramping step started at set point $30{ }^{\circ} \mathrm{C}$ and a linear ramping at $2{ }^{\circ} \mathrm{C} / \mathrm{h}$ to the breakpoint at $55^{\circ} \mathrm{C}$. Second linear ramping was at $4{ }^{\circ} \mathrm{C} / \mathrm{h}$ and reaching a maximum at $82{ }^{\circ} \mathrm{C}$. This temperature was kept constant for $1.5 \mathrm{~h}$. The process was based on a recirculating air flow using $80 \%$ fresh air. The kiln samples were cured using a manual root removal system from Wissenschaftliche Station für Brauerei, Munich, Germany. Final malt samples were stored at $20{ }^{\circ} \mathrm{C}$ prior to near infrared transmittance analysis and enzyme activity measurement.

\section{Malt analysis}

Analysis of malt samples for water content, protein content, soluble protein and extract were determined with a Foss 1241 NIT (Foss A/S, Denmark) instrument using the Malt calibration Foss MA000010 provided by the manufacturer. Prior to enzyme activity analysis the malt samples were milled using a standard Foss Cyclotech mill (Foss A/S, Denmark) equipped with a tungsten carbide grinding ring (Foss 10,004,463), nickel plated impeller (Foss 1000 2666) and a $1 \mathrm{~mm}$ outlet screen (Foss 10,001,989). All enzyme activity measurements of barley malt were made within $48 \mathrm{~h}$ after milling of the dry sample.

\section{a-amylase activity}

$\alpha$-amylase activity of final malt was based on malt flour made according to the sample preparation description in the Malt Analysis section above. $\alpha$-amylase activity assays were measured using a Ceralpha kit (K-CERA) from Megazyme (Ireland) using standard laboratory equipment. The amylase assays were made according to the manufacturer's protocol (K-CERA 01/12). Measurements were made in technical duplicates. Calculation of amylase activity was based on the formula in the Megazyme protocol (K-CERA 01/12). The significance of differences in $\alpha$-amylase activity was tested by a two sided $t$-test for two independent populations with equal variance assumption in Microsoft Excel comparing the four double haploid lines carrying the brh1.a allele to the three lines in their progeny, BW074, Bowman and Quench.

\section{$\beta$-amylase activity}

$\beta$-amylase activity of final malt was based on malt flour made according to the sample preparation description in the Malt Analysis section above. $\beta$-amylase activity assays were measured using Betamyl kit (K-BETA3) from Megazyme (Ireland) using standard laboratory equipment. The amylase assays were made according to the manufacturer's protocol (K-BETA3 10/10). Measurements were made in technical duplicates. Calculation of $\beta$-amylase activity was based on the formula in the Megazyme protocol (K-BETA3 10/10). The significance of differences in $\beta$-amylase activity was tested by a two sided t-test for two independent populations with equal variance assumption in Microsoft Excel comparing the four double haploid lines carrying the brh1.a allele to the three lines in their progeny, BW074, Bowman and Quench. 


\section{Limit dextrinase activity}

Limit dextrinase activity of final malt was based on malt flour made according to the sample preparation description in the Malt Analysis section above. Limit dextrinase activity assays were measured using a Limit Dextrizyme kit T-LDZ1000 from Megazyme (Ireland) using standard laboratory equipment. The limit dextrinase assays were made according to manufacturer's protocol T-LDZ1000 07/9. Measurements were made in technical duplicates. Calculation of limit dextrinase activity was based on the formula in the Megazyme protocol T-LDZ1000 07/9. The significance of differences in Limit dextrinase activity was tested by a two sided $t$-test for two independent populations with equal variance assumption in Microsoft Excel comparing the four double haploid lines carrying the brh1.a allele to the three lines in their progeny, BW074, Bowman and Quench.

\section{Public databases}

Public sequence databases were accessed via the following web pages: "http://www.gramene.org/" for sorghum, "http:// rice.plantbiology.msu.edu/analyses_search_blast.shtml" for rice, and "http://brachypodium.org/" for brachypodium. The NCBI probe database was accessed via the link http:// www.ncbi.nlm.nih.gov/probe. The HarvEST database was accessed using the link http://harvest.ucr.edu/.

\section{Screening of a pooled BAC library of the barley genome} Bacterial artificial chromosome (BAC) clones originating from six independent BAC libraries were previously made from the barley cultivar Morex [27] and pooled in multidimensional levels [2]. Primers specific for the Brh1 target region (Table 2) were obtained from Eurofins MWG Operon, Ebersberg (Germany) and were used for a PCR screening of the pooled BAC libraries to identify $\mathrm{BAC}$ clones containing the region surrounding the Brh1 gene.

\section{PCR amplification and sequencing of the Ga-subunit of the heterotrimeric $\mathrm{G}$ protein in barley}

Oligonucleotides used for PCR amplification and DNA sequencing of the $G \alpha$-subunit of the heterotrimeric $G$ protein are listed in Table 2. PCR amplification from genomic DNA and sequencing of PCR products was done at LGC Genomics GmbH (Berlin, Germany) in the case of all brh1 original mutant lines, near-isogenic lines and the respective mother cultivars. In the case of ari-m mutant lines and their respective mother cultivars, isolation of genomic DNA and PCR amplification was done using the REDExtract-N-Amp ${ }^{\text {Tx }}$ Plant PCR Kit (SigmaAldrich, St. Louis, USA), and sequencing of PCR products was done at StarSEQ (Mainz, Germany).

RNA was isolated from seedlings leaves with the help of Trizol reagent (Thermo Fisher Scientific, Waltham,
USA). For one-step RT-PCR of RNA the SuperscriptIII one-step RT-PCR kit (Thermo Fisher Scientific, Waltham, USA) with HIFI taq enzyme was used. Sequencing of PCR products was done at StarSEQ (Mainz, Germany).

\section{Allelism crosses to confirm identity of the Ari-m and the Brh1 locus in barley}

Allelism tests were performed through crosses between BW074 (brh1.a) and BW051 (ari-m.28). Plants were grown in a greenhouse at $18^{\circ} \mathrm{C}$ under 16 -h-light / 8-hdark cycles. Light intensity were set to a photon flux of $300 \mu \mathrm{mol} \mathrm{m} \mathrm{m}^{-2} \mathrm{~s}^{-1}$. Plants were pollinated 3 days after emasculation. $F_{1}$ progenies of this cross were genotyped to confirm successful crossings, and grown to maturity for phenotypic analysis to confirm allelism through visual inspection of plants.

\section{Results}

Identification of the Brh1 locus

The Brh1 gene is located on barley chromosome 7HS, flanked by markers CDO545 (distal) and R3139 (centromeric) [21]. The two markers are both located $0.8 \mathrm{cM}$ away from the Brh1 locus. A third marker, MWG2074, was shown to co-segregate with the brh1 phenotype in the considered mapping population [21]. Due to the close proximity of the three markers to each other and $B r h 1$, we decided to sequence their neighboring genes in all brh1 mutants in order to identify the Brh1 gene. The work was initiated before barley genomic sequence information was publically available [22]. Therefore, the marker sequences were downloaded from the NCBI probe database and used for blastn analysis of genomic databases. As a first step, sequences and genes homologous to the three barley markers of interest were identified in the genomes of rice (Oryza sativa), sorghum (Sorghum bicolor) and brachypodium (Brachypodium distachyon) (Table 3). We postulated that a syntenic approach could help us to visualize barley genes in the region. However, the comparison showed that the gene content of the Brh1 target region is not fully conserved among the different grass genomes as not all markers flanking the Brh1 locus in barley could be identified in close proximity to each other in any of the rice, sorghum and brachypodium genomes (Fig. 2). The two markers CDO545 and MWG2074, which are flanking the Brh1 locus in barley, were found to be located close to each other on chromosome 1 in brachypodium. Further, six genes were present in the region of interest in all three organisms investigated (green and gray arrows in Fig. 2b). In case of five of these genes, a unigene could be identified in the barley EST database HarvEST (http://harvest.ucr. $\mathrm{edu} /$ ). Primers were designed for these unigenes and a PCR-based screening of pooled BAC libraries was performed. We identified ten BAC clones, located in two 
Table 2 Oligonucleotides used as PCR primers to amplify and sequence the gene encoding the Ga-subunit of the heterotrimeric G protein and to amplify gene fragments located in the genomic region surrounding this gene in a BAC pool screening

\begin{tabular}{|c|c|c|c|}
\hline Primer name & Sequence $\left(5^{\prime} \rightarrow 3^{\prime}\right)$ & Template & Length of amplification product [bp] \\
\hline bw-Fr1-F1 & TGTCAAGATGATGGCTTCAG & Genomic DNA & 703 (with bw-Fr1-R1) \\
\hline bw_Fr1-Fseq & AAAAAGACGATGATGAAGC & Genomic DNA & \\
\hline bw-Fr1-R1 & GATCGACGAGAGCATGAGAC & Genomic DNA & \\
\hline bw-Fr2-F1 & GGCGAGGTAGAAAGCAAAAG & Genomic DNA & 790 (with bw-Fr2-R1) \\
\hline bw-Fr2-R1 & TITGAGGTATCCATCCATCTC & Genomic DNA & \\
\hline bw-Fr3-F1 & CGCACACAGTCAAAGGAAC & Genomic DNA & 896 (with bw-Fr3-R1) \\
\hline bw-Fr3-R1 & GACAGCATTGCACAAGGAG & Genomic DNA & \\
\hline bw-Fr4-F1 & TGTCCCAGATCCTCAAACTG & Genomic DNA & 901 (with bw-Fr4-R1) \\
\hline bw-Fr4-R1 & TTGTCCCTTGTAAACTGTTGG & Genomic DNA & \\
\hline bw-Fr5-F1 & TCCTCCTGCAAAATCTCTCC & Genomic DNA & 903 (with bw-Fr5-R1) \\
\hline bw-Fr5-R1 & TTAGACTCGGCATTTTGAGG & Genomic DNA & \\
\hline bw-Fr6-F1 & ACCTGAATGGCTGGATCTTC & Genomic DNA & 857 (with bw-Fr6-R1) \\
\hline bw-Fr6-R1 & GCATAGTGGGGATTATTCAGG & Genomic DNA & \\
\hline bw-Fr7-F1 & GGTCCAAACAGGTTCAGTTG & Genomic DNA & 824 (with bw-Fr7-R1) \\
\hline bw-Fr7-R1 & GATTCTGCACGAGACAAAGG & Genomic DNA & \\
\hline bw-Fr8-F1 & GGAATCAGTCTITCCAGATCC & Genomic DNA & 705 (with bw-Fr8-R2) \\
\hline bw-Fr8-R2 & CCAAAATACCCATACCAACC & Genomic DNA & \\
\hline bw-Fr9-F1 & GAGCGAGCCAGAGATTTTG & Genomic DNA & 711 (with bw-Fr9-R1) \\
\hline bw-Fr9-R1 & TGTATATGACGGAGCAGCAAG & Genomic DNA & \\
\hline bw_Frg-Rseq & GCTTGTTGGTTGTAGCTCAG & Genomic DNA & \\
\hline IL130 & CAACAATATGGGCATTACAT & BAC & 350 (with IL131) \\
\hline IL131 & CGAGGAGTTCTACAAATCAT & BAC & \\
\hline IL132 & CTTGCCCACTTACCAGGTGG & BAC & 300 (with IL133) \\
\hline IL133 & ACGGGATCTCCTTATGGAGC & BAC & \\
\hline IL134 & ATGATCGACTGCTACATCC & BAC & 318 (with IL135) \\
\hline IL135 & GGTTCTGTCGTTGTACCTAG & BAC & \\
\hline IL136 & CACCAAGCAGCAGATGATC & BAC & 152 (with IL137) \\
\hline IL137 & CCAGTTGTTGGATGTTTCC & $B A C$ & \\
\hline IL138 & GAGGGCTTCTATTGAAAGTG & BAC & 510 (with IL139) \\
\hline IL139 & GGTACTGACCAACTGTTACG & $B A C$ & \\
\hline IL140 & AAAAGGCTGACTCAAAGACC & BAC & 318 (with IL141) \\
\hline IL141 & CGACAAGCTCCATAAGGTAC & BAC & \\
\hline IL142 & TCTGACCCAGAAACTTGATC & BAC & 651 (with IL143) \\
\hline IL143 & GAAAGGGAGAGAGAAATCG & BAC & \\
\hline IL144 & GGTCTGACCTCTTATTTCCC & BAC & 512 (with IL 145) \\
\hline IL145 & AAAGCGAGGCATTCACTAG & BAC & \\
\hline IL146 & GCTCAAAGTGGGAATACGAG & BAC & 475 (with IL147) \\
\hline IL147 & CTTGTGCTGCCAACTAGATG & BAC & \\
\hline IL148 & AAGAGCATCCAGTGACAAG & BAC & 633 (with IL149) \\
\hline IL149 & GGATCTCCGCTTAGGTATAG & BAC & \\
\hline IL150 & CGCTTTCCCTATTTTGTCAG & BAC & 576 (with IL151) \\
\hline |L151 & ACTTCACGGAGATTGATGC & BAC & \\
\hline
\end{tabular}


Table 2 Oligonucleotides used as PCR primers to amplify and sequence the gene encoding the Ga-subunit of the heterotrimeric G protein and to amplify gene fragments located in the genomic region surrounding this gene in a BAC pool screening (Continued)

\begin{tabular}{|c|c|c|c|}
\hline IL152 & AGCCAGCAATCCTTGTTAGC & BAC & 510 (with IL153) \\
\hline IL153 & ACCTTGAGCCAGGGAAAAG & BAC & \\
\hline IL201 & CTCTGGCTCGCTCATCAACC & RNA & 1229 (with IL202) \\
\hline IL202 & AGCGTCTCATGCTCTCGTCG & RNA & \\
\hline IL203 & GTAAACGAGGCAGAGGCAGC & RNA & 461 (with IL204) \\
\hline IL204 & CAGTCGGGAACTTGCAGCAC & RNA & \\
\hline IL205 & CGGAACTCAAGGGCTACACG & RNA & 600 (with IL206) \\
\hline IL206 & CGAACAGCTCCTTGGTCTCC & RNA & \\
\hline IL207 & AAATCTCTGGCTCGCTCATC & RNA & 1389 (with IL208) \\
\hline IL208 & AGCACAAAGGAGTCACAAGG & RNA & \\
\hline IL209 & ACTAGGAGGAAGCATGAGAC & RNA & 1305 (with IL210) \\
\hline IL210 & CAATACAGAGTTGCGACACC & RNA & \\
\hline
\end{tabular}

finger-print contigs on chromosome $7 \mathrm{H}$. The two fingerprint contigs, 44,369 and 44,201, were both anchored to the genomic position at $12.74 \mathrm{cM}$ on chromosome $7 \mathrm{H}$ (17). The BAC clones identified in the PCR-screen were overlapping with three sequenced BAC clones (17), providing us with a partial sequence of the Brh1 target region in barley. The six genes predicted to be located in this region could all be identified on the sequenced BACs. The three sequenced BAC clones were searched for appropriate candidate genes for the Brh1 mutation. On BAC clone HVVMRX83KHA0060C10 we could identify the Morex locus MLOC_67224.3, a sequence corresponding to the NCBI accession AF267485. This gene encodes the G $\alpha$ subunit of a heterotrimeric $G$ protein in barley. Mutations in the $\mathrm{G \alpha}$ subunit are known to be the cause of the semidwarf phenotype in the $d w a r f 1(d 1)$ rice mutants [4], making the $G \alpha$ subunit a promising candidate gene for the brh1 mutation in barley. Still, the location of the barley gene was a surprising finding. The $D 1$ gene in rice (locus Os05g26890) is located on chromosome 5 and not in the region on chromosome 6 , which was shown to be syntenic to the Brh1 region in barley [21]. Further, blastp analyses identified Sb01g045320 in sorghum and Bradi2G60350 in brachypodium as the orthologous genes of barley Brh1. Neither of the sorghum and brachypodium genes are in regions syntenic to barley.

\section{Brh1 encodes the Ga subunit in barley}

Mutations in the gene encoding the $G \alpha$ subunit in rice cause the $d 1$ mutant phenotype, a semi-dwarf phenotype similar to the brh 1 phenotype in barley. Rice $d 1$ mutants are characterized by reduced plant height, shorter panicles, and shorter, globe-shaped seeds [4]. The barley brh1 mutation also causes height reduction, changes in the spike architecture and is characterized by a rounded seed shape (Fig. 1). The matching rice phenotype and the localization of the G $\alpha$ gene in the $b r h 1$ target region

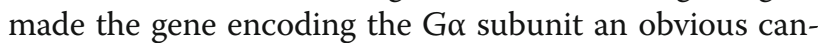
didate gene for the brh1 mutation. Therefore, we sequenced the gene in the brh1 near-isogenic lines and in the cultivar Bowman. In each of the eight near-isogenic lines, but not in Bowman, a mutation was found with strong postulated impact on the resulting protein (Fig. 3, Table 4). In BW076 (brh1.ae) only two of the nine PCR fragments that were generated for sequencing of the Brh1 gene could be amplified from genomic DNA suggesting a partial deletion of the gene in this mutant line. Small deletions of 1 or 2 bp caused frame shifts in BW047 (ari-i.38), BW075 (brh1.aa), BW077 (brh1.e), BW078 (brh1.t) and BW080 (brh1.z). The frame shifts introduced premature stop codons in all lines except BW074 (brh1.a) where a new stop codon was introduced in the $3^{\prime}$ untranslated region after a frame shift, thus

Table 3 Markers in the vicinity of Brh1 [21] and the gene models associated with the best blastn hit in the genomes of rice, sorghum and brachypodium

\begin{tabular}{lllll}
\hline Marker & NCBI accession no. & Rice blast hit & Sorghum blast hit & Brachypodium blast hit \\
\hline CDO545 & AA231869.1 & Os06g02550.2 & Sb10g001310 & Bradi1g50590.1 \\
AA231713.1 & & & Bradi1g50650.1 \\
R3139 & AJ234755.1 & no hit on chromosome 6 & no hit on chromosome 10 & Bradi1g50660.1 \\
& AJ234754.1 & & & no conclusive hit \\
& AU082160 & Os06g03560 & Sb10g001530 & (with D25093) \\
\hline
\end{tabular}




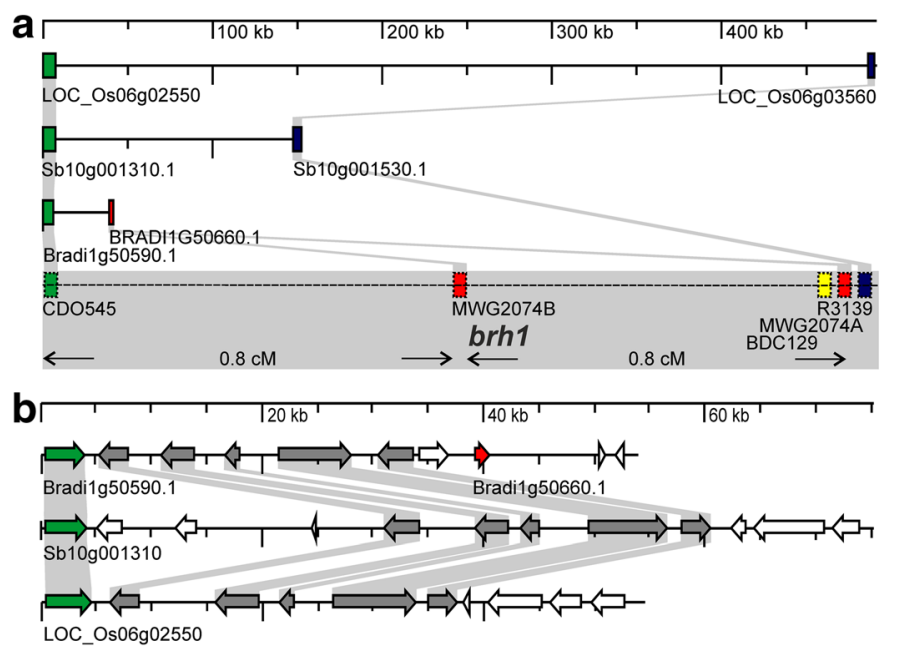

$\begin{aligned} & \text { O. sativa } \\ & \text { chr6:885000..1376000 } \\ & \text { S. bicolor } \\ & \text { chr10: } 1083000 \text { - } 1235770 \\ & \text { B. distachyon } \\ & \text { chr1: } 49180000 . .49222200\end{aligned}$
H. vulgare (Li et al. 2001)
$\begin{aligned} & \text { B. distachyon } \\ & \text { chr1: } 49180000 . .49235000\end{aligned}$
$\begin{aligned} & \text { S. bicolor } \\ & \text { chr10: } 1085500 . .1161000\end{aligned}$
$\begin{aligned} & \text { O. sativa } \\ & \text { chr6: } 884000 . .942000\end{aligned}$

Fig. 2 The Brhl genomic region in barley and the syntenic regions in rice, sorghum and brachypodium. a. Brhl has been mapped between markers CDO545 (green, NCBI accession numbers AA231869.1 and AA231713.1) and BDC129 (yellow), R3139 (blue, AU082160, D25093) and MWG2074 (red, AJ234754.1, AJ234755.1) [21]. MWG2074 was shown to have two loci, the B locus (middle, red) was co-segregating with Brh1. Marker sequences were used to identify matching loci in rice, sorghum and brachypodium (color codes kept). No obvious hits to orthologous sequences could be found for marker MWG2074 in rice and sorghum, or for R3139 in brachypodium. b. Gene content of the Brh1 syntenic region in brachypodium as identified in Fig. 2a. The loci (Bradi1g50590 and Bradi1g50660) matching markers CDO545 and MWG2074 are highlighted green and red, respectively. The genes flanked by loci Bradi1g50590 and Bradi1g50660 are found in the same order in rice and sorghum. The orthologous barley genes were used to screen pooled BAC libraries

extending exon 13. In BW079 (brh1.x) a point mutation introduced a premature stop deleting the last 20 amino acids of the protein.

We also sequenced the gene encoding the $\mathrm{G} \alpha$ subunit from the original mutants and two additional lines, brh1.c and brh1.f, for which no near-isogenic lines have been generated (Fig. 3, Table 4). All mutations were verified and they were not present in the respective mother cultivar (Table 1). Mutation brh1.c was based on a $2 \mathrm{bp}$ deletion and identical to brh1.a. Mutation brh1.f was based on a 4 bp deletion in exon 6 leading to a premature stop. We noticed several SNPs between Bowman and the mother cultivars (Bonus, Himalaya, Steptoe, Moravian, Aramir, Domen, Akashinriki and Volla) with the exception of Aapo, which was identical to Bowman over the sequenced region (Additional file 1 Table S1).
We noted that the SNP pattern in mutant brh1.c was not the same as its mother cultivar Moravian. Instead they were identical to those of brh1.a and Himalaya. Still mature plants of the mutant lines brh1.c and brh1.a show different morphological characters - brh1.c is tworowed, while brh1.a is six-rowed. We therefore suggest that the brh1 mutation was introduced into Moravian by crossing to a brh1.a mutant line instead of an independent mutational event.

\section{Identification of additional brh1 alleles}

When propagating various near-isogenic lines, we noticed that BW051 (ari-m.28) has a brh1-like phenotype with overall reduction in height and characteristic short awns. In addition, the introgression residing from the original mutant donor ari-m.28 in BW051 is reduced to

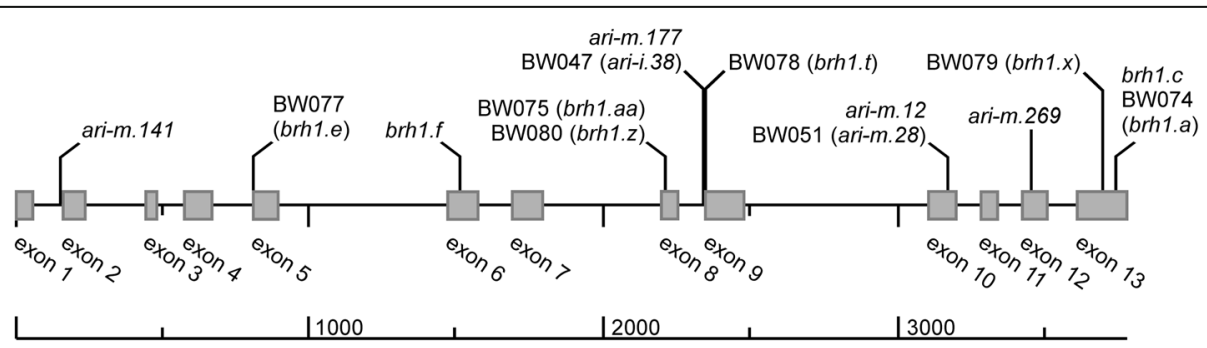

Fig. 3 Distribution of mutations identified in the gene of the Ga subunit of the heterotrimeric G protein in brh1, ari-i and ari-m barley mutants. The gene contains 13 exons and 12 introns over 3780 bp. The deduced polypeptide is 383 amino-acid residues. More detailed information about the mutations is found in Table 4. Mutations brh1.ae and ari-m.251 are large deletions of $>3 \mathrm{~kb}$ not shown in the figure 
Table 4 Mutations identified in recessive brh1 alleles and their deduced effect at protein level

\begin{tabular}{|c|c|c|c|}
\hline Allele & $\begin{array}{l}\text { Position of } \\
\text { mutation }^{a}\end{array}$ & Type of mutation & Effect of mutation on protein \\
\hline $\begin{array}{l}\text { BW047 } \\
\text { (ari-i.38) }\end{array}$ & 2345 & a to $t$ & $\begin{array}{l}\text { Mutation shifts splice site between intron } 8 \text { and exon } \\
9 \text { leading to frame shift. } 203 \text { native amino-acid residues followed by FSAAPLERAKEAERYTGCMM. }\end{array}$ \\
\hline $\begin{array}{l}\text { BW074 } \\
(b r h 1 . a)\end{array}$ & $3745-3746$ & 2 bp deletion & $\begin{array}{l}\text { Frame shift eliminates wild type stop codon and extends exon } 13.372 \text { native residues followed by } \\
152 \text { additional aa residues. }\end{array}$ \\
\hline $\begin{array}{l}\text { BW075 } \\
\text { (brh1.aa) }\end{array}$ & 2205 & 1 bp deletion & $\begin{array}{l}\text { Frame shift in exon } 8.185 \text { native residues followed } \\
\text { by MCSMQEYGQMGL. }\end{array}$ \\
\hline $\begin{array}{l}\text { BW076 } \\
\text { (brh1.ae) }\end{array}$ & $\begin{array}{l}\text { Deletion (minimal } \\
\text { region: }-723 \text { to } \\
2819\end{array}$ & $\begin{array}{l}\text { Large deletion, no } \\
\text { transcript detectable }\end{array}$ & Probably no protein produced \\
\hline brh1.c & $3745-3746$ & 2 bp deletion & $\begin{array}{l}\text { Frame shift eliminates wild type stop codon and extends } \\
\text { exon } 13.372 \text { native residues followed by } 152 \text { additional } \\
\text { residues. }\end{array}$ \\
\hline $\begin{array}{l}\text { BW077 } \\
(\text { brh1.e) }\end{array}$ & 813 & $\mathrm{~g}$ to a & $\begin{array}{l}\text { Mutation eliminates splice site between intron } 4 \text { and } \\
\text { exon } 5 \text { leading to frameshift. } 88 \text { native residues } \\
\text { followed by VCYYWKGCVSYLFHLLHSGDYSGNLHWI } \\
\text { FLWECYYTSYY. }\end{array}$ \\
\hline brh1.f & $1512-1515$ & 4 bp deletion & $\begin{array}{l}\text { Frame shift and premature stop in exon } 6.129 \text { native } \\
\text { residues followed by SLIKNSYRM. }\end{array}$ \\
\hline $\begin{array}{l}\text { BW078 } \\
(b r h 1 . t)\end{array}$ & 2346 & $\mathrm{~g}$ to $\mathrm{a}$ & $\begin{array}{l}\text { Mutation shifts splice site between intron } 8 \text { and exon } \\
\text { 9. } 203 \text { native residues followed by FSATPLERAKEV } \\
\text { ERYTGCMM. }\end{array}$ \\
\hline $\begin{array}{l}\text { BW079 } \\
(\text { brh 1.x) }\end{array}$ & 3718 & a to $t$ & $\begin{array}{l}\text { Premature stop in exon 13. Truncated protein of } 363 \\
\text { residues. }\end{array}$ \\
\hline $\begin{array}{l}\text { BW080 } \\
(b r h 1.2)\end{array}$ & 2205 & 1 bp deletion & $\begin{array}{l}\text { Frame shift in exon } 8.185 \text { native residues followed } \\
\text { by MCSMQEYGQMGL. }\end{array}$ \\
\hline $\operatorname{ari}-m .12$ & 3178 & $g$ to a & $\begin{array}{l}\text { Premature stop in exon 10. Truncated protein of } 270 \\
\text { native residues. }\end{array}$ \\
\hline $\begin{array}{l}\text { BW051 } \\
\text { (ari- } \\
m .28)\end{array}$ & 3178 & $g$ to a & $\begin{array}{l}\text { Premature stop in exon 10. Truncated protein of } 270 \\
\text { native residues. }\end{array}$ \\
\hline $\begin{array}{l}\text { ari- } \\
m .141\end{array}$ & 164 & $g$ to $a$ & $\begin{array}{l}\text { Mutation eliminates splice site between intron } 1 \text { and } \\
\text { exon 2. } 21 \text { native residues followed by VSSFPYHLLD } \\
\text { SFNSSCPVLSCPVLS. }\end{array}$ \\
\hline $\begin{array}{l}\text { ari- } \\
m .177\end{array}$ & 2345 & a to $t$ & $\begin{array}{l}\text { Mutation shifts splice site between intron } 8 \text { and exon } \\
9 \text { leading to frame shift. } 203 \text { native } \\
\text { residues followed by FSAAPLERAKEAERYTGCMM. }\end{array}$ \\
\hline $\begin{array}{l}\text { ari- } \\
m .251\end{array}$ & & Large deletion & No protein produced. \\
\hline $\begin{array}{l}\text { ari- } \\
m .269\end{array}$ & 3449 & $\mathrm{~g}$ to a & $\begin{array}{l}\text { Premature stop in exon 12. Truncated protein of } 306 \\
\text { residues. }\end{array}$ \\
\hline
\end{tabular}

The deduced polypeptide of Brh1 (AF267485) is 383 amino-acid residues

aFirst position is the "A" of the ATG start codon in the Bowman genomic sequence

a minor genetic element in the telomeric region of chromosome 7HS overlapping with the introgression regions of all brh1 Bowman near-isogenic lines (Table 1,

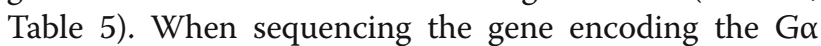
subunit in BW051 we found a single nucleotide substitution in exon 10 leading to a premature stop codon (Fig. 3, Table 4). The same mutation was found in the original mutant line ari-m.28, which was isolated in the cultivar Bonus [20]. We also performed a cross between BW074 (brh1.a) and BW051 (ari-m.28). The $F_{1}$ plants displayed a semi-dwarf and short-awn mutant phenotype, which further proves that ari-m.28 and brh1. $a$ are allelic (Fig. 4).

In addition to ari-m.28, five other ari-m alleles are available (Table 5) (www.nordgen.org/bgs). A mutation in the gene encoding the G $\alpha$ subunit could be identified in each of them (Fig. 3, Table 4). The mutations found in ari-m.12 and ari-m.28 are identical nucleotide substitutions introducing stop codons in exon 10. Mutant line ari-m.177 was identical to ari-i.38 (BW047), affecting a splice site between intron 8 and exon 9. Line ari-m.141 also showed a mutation in a splice site - between intron 


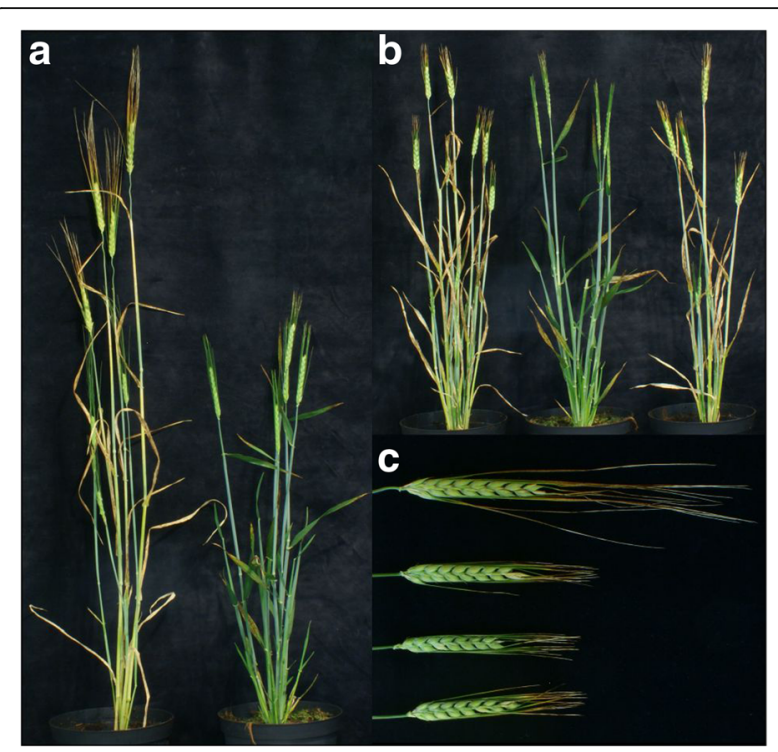

Fig. 4 Phenotype of $F_{1}$ plants generated from a cross between the Bowman near-isogenic lines BW051 (ari-m.28) and BW074 (brh 1.a). a. Overall height of cultivar Bowman (left) compared to an $\mathrm{F}_{1}$ plant of a cross between BW051 x BW074. b. Overall height of BW051 x BW074 $F_{1}$ plant (middle), BW051 (left) and BW074 (right), carrying the recessive ari-m.28 and brh1.a alleles, respectively. c. Awn phenotypes of Bowman (top), BW051, F 1 of BW051 x BW074 and BW074

1 and exon 2. Mutation ari-m.269 is a nucleotide substitution introducing a stop codons in exon 12 . Finally, ari$m .251$ is a large deletion since no parts of the Brh1 locus could be amplified by PCR.

\section{Transfer of the brh1 mutation to a modern elite malting barley background}

The available brh1 mutant alleles have been generated in several genetically different mother cultivars. In our trials, they all showed a pronounced reduction in culm length and awn length (Fig. 5). To the best of our knowledge, none of the described brh1 alleles have been

Table 5 Summary of breviaristatum-m (ari-m) alleles, their genetic backgrounds, their availability as Bowman near-isogenic lines, and introgression regions on chromosome $7 \mathrm{H}$

\begin{tabular}{|c|c|c|c|}
\hline Allele & $\begin{array}{l}\text { Genetic } \\
\text { background }\end{array}$ & $\begin{array}{l}\text { Bowman near- } \\
\text { isogenic line }\end{array}$ & $\begin{array}{l}\text { Introgression } \\
\text { region on } \\
7 \mathrm{HS}(\mathrm{cM})\end{array}$ \\
\hline $\operatorname{ari-m} .12^{a}$ & Bonus & no line available & - \\
\hline $\operatorname{ari}-m \cdot 28^{a}$ & Bonus & BW051 $1^{\mathrm{a}}$ & $4.74-9.55$ \\
\hline $\operatorname{ari-m} .141^{a}$ & Foma & no line available & - \\
\hline $\operatorname{ari}-m .177^{a}$ & Foma & no line available & - \\
\hline $\operatorname{ari-m} .251^{a}$ & Kristina & no line available & - \\
\hline $\operatorname{ari-m} .269^{a}$ & Kristina & no line available & - \\
\hline
\end{tabular}

The near-isogenic line has been prepared previously as well as the determination of the introgression region [11]

${ }^{\text {a }}$ Source of seed material: Nordic Genetic Resource Center, Alnarp, Sweden tested in European breeding material. Therefore, we performed crosses between the Bowman near-isogenic line BW074 (brh1.a) and the European elite malting cultivar Quench. Double-haploid plants were generated. Two independent double-haploid lines, designated DH_A and DH_B that displayed the phenotype characteristic for brh1 mutant lines, were selected. These lines were propagated and finally tested under field conditions in two subsequent years (Fig. 6). It was observed that cultivar Bowman produced significantly lower grain yield than cultivar Quench. This was expected, as Bowman is a North American cultivar while Quench was bred for agriculture in Europe. Mutant line BW074 had a yield comparable to that of Bowman. The double-haploid lines yielded higher than Bowman and BW074 but lower than Quench. A repetition of the field trial with a reduced number of lines in the following year gave similar results (Fig. 6b). We conclude that the yield of brh $1 \mathrm{mu}$ tant lines can be significantly increased by backcrossing to a modern elite line.

\section{The effect of the brh1 mutation on malting quality}

The brh1 double-haploid lines generated in this study were tested in laboratory scale micro malting experiments together with the near-isogenic line BW074 (brh1.a) and the cultivars Quench and Bowman. We measured the activity of three key starch degrading enzymes $\alpha$-amylase, $\beta$-amylase and free limit dextrinase (Fig. 7). The brh1 double-haploid lines showed an increase in activity, especially for $\beta$-amylase and free limit dextrinase activity. The reason for this observation remains elusive but can partly be caused by a changed volume-area ratio in the global shaped $b r h 1$ seeds. Still, the presented results do not indicate that the brh1 mutation has a negative effect on malting quality in barley.

\section{Discussion}

While there are several genes encoding $G \alpha, G \beta$ and $G \gamma$ subunits of heterotrimeric $G$ proteins in mammals, there is only one $G \alpha$, one $G \beta$ and three $G \gamma$ encoding genes in arabidopsis, and one $G \alpha$, one $G \beta$ and four $G \gamma$ genes in rice [29]. Analysis of the recently sequenced barley genome $[22,17]$ ) reveals one $\mathrm{G \alpha}$ (gene identity in Mascher et al. [22] HORVU7Hr1G008720.11), one G $\beta$ (HORVU4Hr1G003110.4) and four $\mathrm{G \gamma}$ genes (HORVU5Hr1G093530.3, HORVU5Hr1G093550.1, AK367089, HORVU5Hr1G061840.7). In mammalian systems, binding of a ligand to the G-protein-coupled receptor causes a

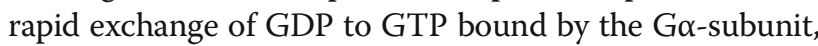
which promotes a dissociation of activated G $\alpha$-GTP from

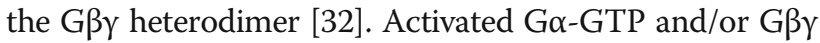
interacts with effector proteins. A different system for Gprotein signaling is found in plants. The arabidopsis $G \alpha$ subunit spontaneously binds GTP in vitro [19] but its 

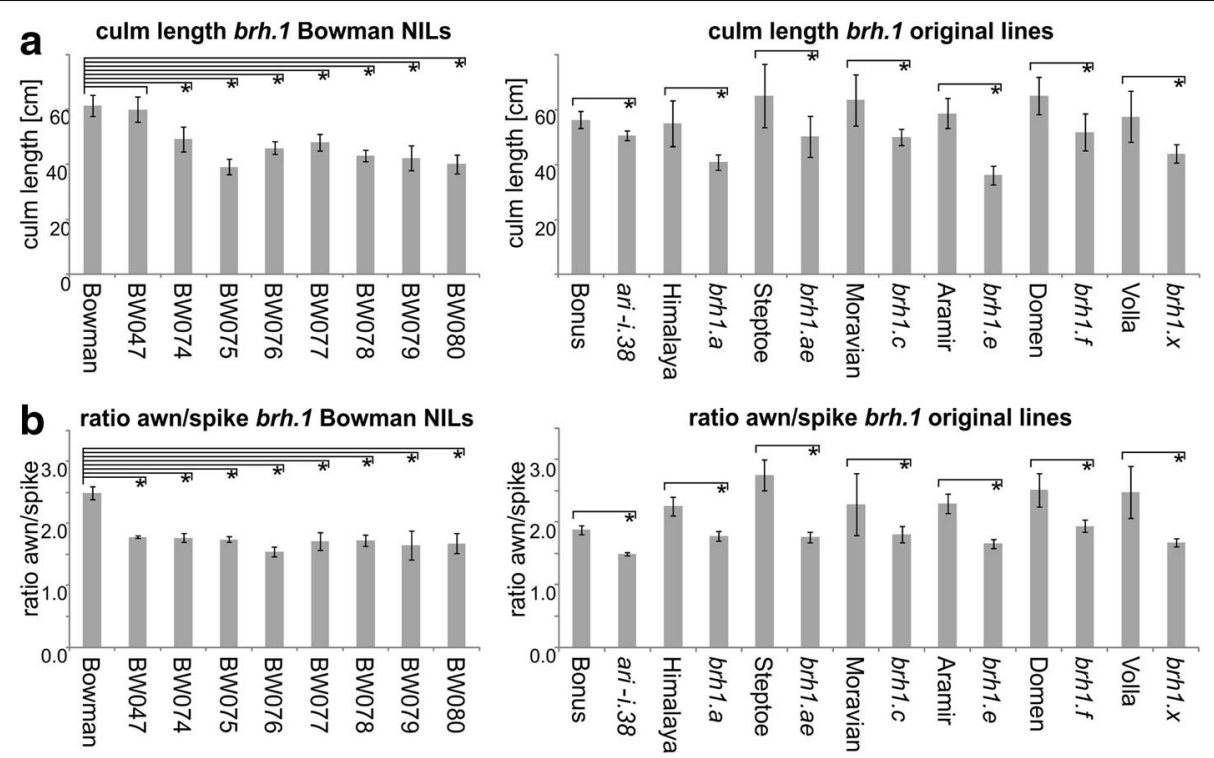

Fig. 5 Culm length (a) and awn/spike ratio (b) in brh1 mutants compared to their respective mother cultivars. The plants were grown in a green house. A $p$-value of $<0.05$ was considered as significant and indicated with an asterisk in the figure

ability to stimulate effector molecules is inhibited by its association to a membrane bound Regulator-of-G-protein-signaling (RGS) protein [34]. Upon binding of a ligand to the RGS protein, the Go-GTP subunit is released and can interact with effector molecules.

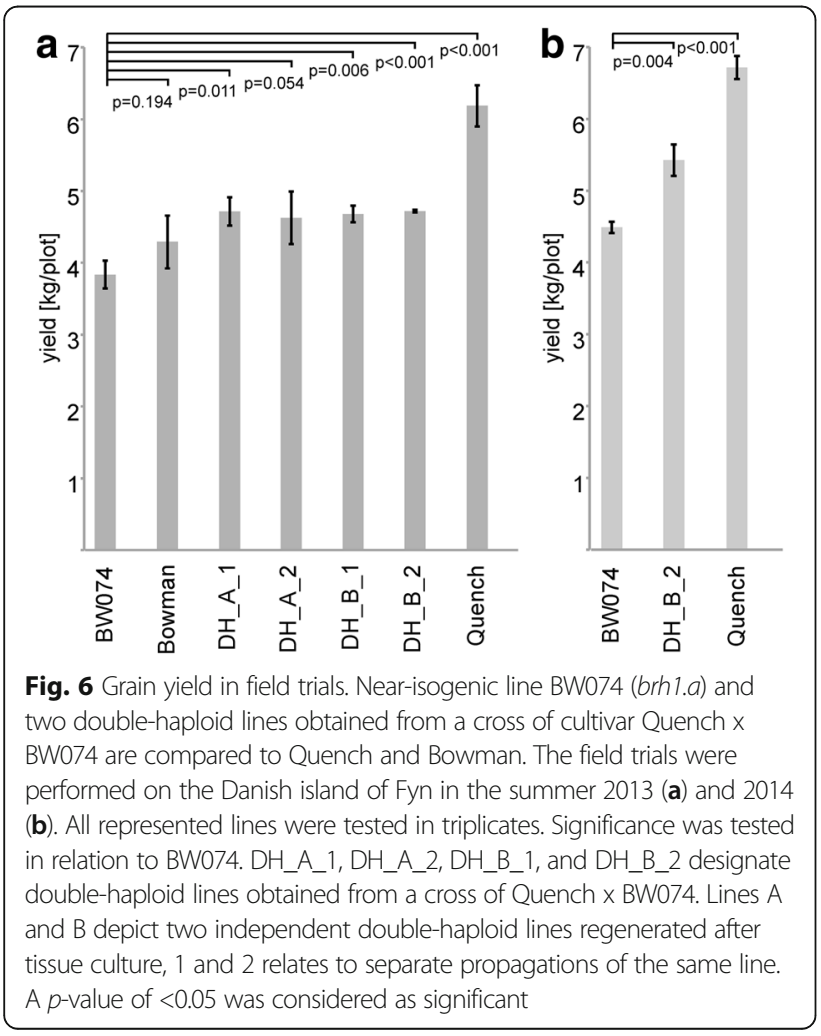

In the present study we demonstrated that barley Brh1 is orthologous to rice $D 1$ encoding a Go-subunit of a heterotrimeric $G$ protein [4]. In addition, we characterized nine brh1, one ari-i and six ari-m mutants at the DNA level, and demonstrate that Ari- $m$ is allelic to Brh1. It has previously been reported that Brh1 and Ari$i$ are allelic [33]. All sixteen mutations result in severe changes of the Brh1 gene and gene product - deletions, nonsense mutations or frame shifts leading to modified polypeptides. It was recently shown that the barley Ari-e encodes a $\mathrm{G \gamma}$ subunit of a heterotrimeric G protein $[18,35]$, being orthologous to $D E P 1$ in rice [16]. Further, the gene product of TUD1 in rice, a Ubox E3 ubiquitin ligase, has been suggested to directly interact with the rice $G \alpha$ subunit and is therefore directly responsible for the turnover of heterotrimeric $G$ proteins [15]. We found recently that barley Brh2 is orthologous to TUD1 in rice (Braumann et al. unpublished). Barley brh1, brh2 and ari-e mutants have short-culm phenotypes, which is now understood in the light of their connection to the heterotrimeric $\mathrm{G}$ protein.

Although genes encoding subunits of the heterotrimeric $\mathrm{G}$ protein complex now start to be identified, it is still not clear in which signaling pathway the complex is participating. The response to both brassinosteroids and gibberellic acids have been investigated for brh1 mutants in previous studies. In contrast to $u z u$ mutants, brh1 mutants are brassinosteroid sensitive [14], making it unlikely that brh1 is part of the brassinosteroid signaling pathway. It has further been shown that application of gibberellic acid leads to increased elongation of brh1 plants in a similar extend as for wild type plants. Still, 

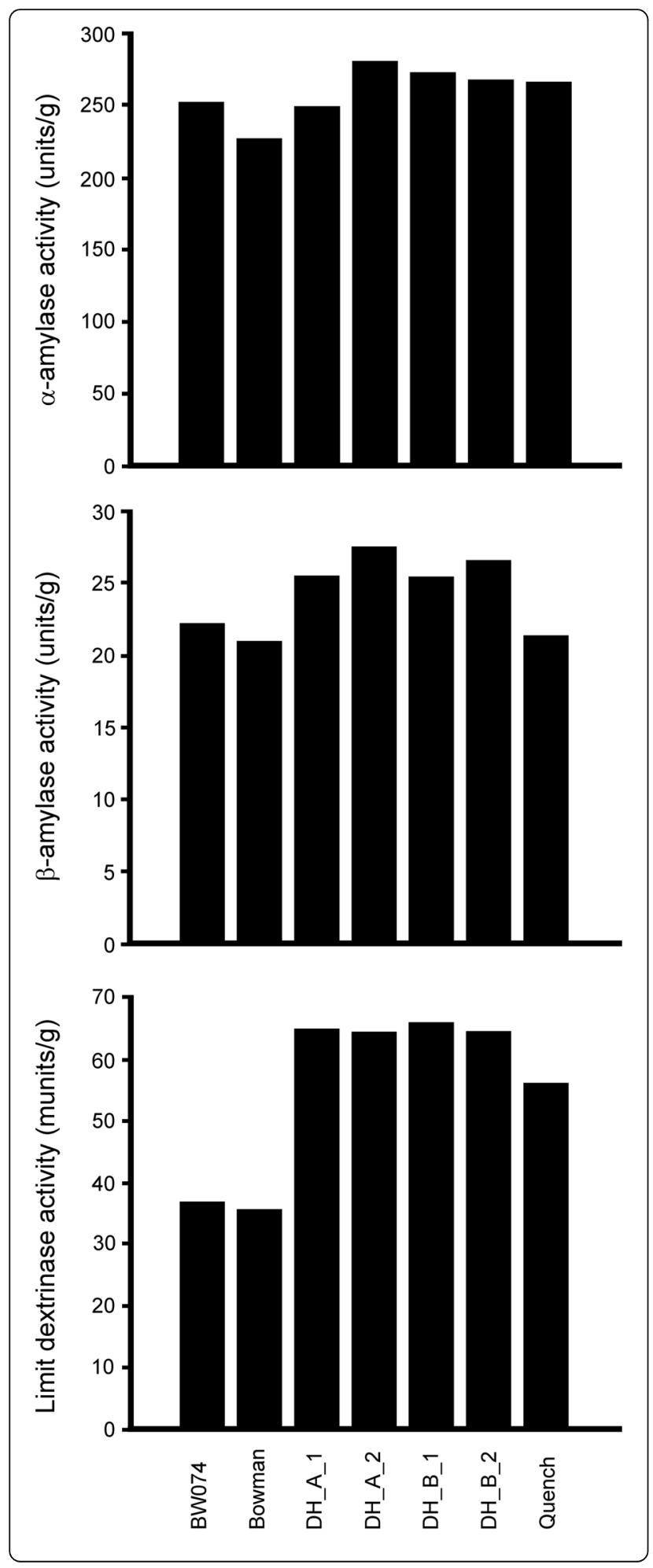

Fig. 7 Measurement of a-amylase, $\beta$-amylase and free limit dextrinase activity in malt samples obtained from near-isogenic line BW074 (brh 1.a), two double-haploid lines obtained from a cross of cultivar Quench $x$ BW074, and of cultivars Quench and Bowman. Two measurements per sample were performed. Standard deviations are indicated in the figure. The averages of the activities of the double-haploid lines were compared to the average of the activities of BW074, Bowman and Quench in a t-test, which revealed significant differences in enzyme activities for $\beta$-amylase and free limit dextrinase $(p<0.05)$

both gibberellic acid treated and untreated brh1 plants are significantly shorter than wild type plants that had received the same treatment [5]. These findings disprove the direct involvement of the Brh1 gene in either gibberellic acid signaling or biosynthesis.

Dahleen et al. [8] did a detailed study of the agronomic performance of five recessive $b r h 1$ lines BW047 (ari-i.38), BW074 (brh1.a), BW078 (brh1.t), BW080 (brh1.z) and BW075 (brh1.aa). The parameters including plant height, lodging, yield, number of kernels per spike and kernel weight. All brh1 plants were shown to be significantly shorter and more lodging resistant than the cultivar Bowman. The mutants displayed a lower kernel weight but otherwise yields were like Bowman with the exception of BW075 (bri1.aa), which yielded lower. Based on their results it was concluded that the brh1 mutations introduce agronomically valuable traits like shorter plant stature and lower lodging potential while negative effects of the mutation on agronomical key traits like yield seem to be neglectable [8]. Our study indicated a lower yield due to the brh1 mutation but we assume that recurrent backcrossing to Quench would increase the yield like it did in the Bowman near-isogenic lines studied by Dahleen et al. [8]. More important, our results showed no negative effect on malting qualities due to the brh1 mutation. We therefore suggest that Brh1 might be a competitive breeding alternative to other used semi-dwarfing genes like Ari-e, Ert-k, Sdw1, $S d w 4$ and $U z u 1$.

\section{Conclusions}

Mutants in the Brh1 locus are deficient in the Go subunit of a heterotrimeric $G$ protein, which shows that heterotrimeric $\mathrm{G}$ proteins are important regulators of culm length in barley. It is still not clear in which signaling pathway the complex is participating. Sixteen mutant alleles were characterized at DNA level and display a repertoire of deletions and nucleotide substitutions. While our study suggests a lower yield due to mutations in Brh1, we did not see any negative effects on malting quality. Thus, brh1 mutant alleles might be used in order to breed for robust and lodging resistant malting barley cultivars. 


\section{Additional file}

Additional file 1: Table S1. SNP and mutation information for Brh1 mutant lines and original background cultivars. (XLSX $121 \mathrm{~kb}$ )

\section{Acknowledgements}

This study was supported by the Carlsberg Foundation, Grønt Udviklings- og Demonstrations Program (GUDP, Denmark, 34009-12-0522), Deutsche Forschungsgemeinschaft (Germany, D01482/1-1), the Crafoord Foundation (20150748) and the CF Lundström Foundation.

\section{Funding}

This study was supported by the Carlsberg Foundation, Grønt Udviklings- og Demonstrations Program (GUDP, Denmark, 34,009-12-0522), Deutsche Forschungsgemeinschaft (Germany, DO1482/1-1), the Crafoord Foundation (20150748) and the CF Lundström Foundation.

\section{Availability of data and materials}

Not applicable.

\section{Authors' contributions}

$\mathrm{IB}, \mathrm{CD}, \mathrm{SB}, \mathrm{AH}, \mathrm{FL}, \mathrm{UL}, \mathrm{SZ}$ and RZ performed experiments. IB, BS, NS and $\mathrm{MH}$ designed research. IB and $\mathrm{MH}$ wrote the paper. All authors read and approved the final manuscript.

\section{Ethics approval and consent to participate}

Not applicable.

\section{Consent for publication}

Not applicable.

\section{Competing interests}

The authors declare that they have no competing interests.

\section{Publisher's Note}

Springer Nature remains neutral with regard to jurisdictional claims in published maps and institutional affiliations.

\section{Author details}

'Carlsberg Research Laboratory, J. C. Jacobsens Gade 4, DK-1799 Copenhagen V, Denmark. 'Leibniz Institute of Plant Genetics and Crop Plant Research (IPK), OT Gatersleben, DE-06466 Stadt Seeland, Germany. ${ }^{3}$ Nordic Genetic Resource Center (NordGen), Smedjevägen 3, SE-23053 Alnarp, Sweden. ${ }^{4}$ Department of Biology, Lund University, Sölvegatan 35, SE-22362 Lund, Sweden

Received: 22 April 2017 Accepted: 21 August 2017

Published online: 05 September 2017

\section{References}

1. Ahloowalia BS, Maluszynski M, Nichterlein K. Global impact of mutation-derived varieties. Euphytica. 2004;135:187-204.

2. Ariyadasa R, Stein N. Advances in BAC-based physical mapping and map integration strategies in plants. J Biomed Biotechnol. 2012;2012:184854.

3. Ashikari M, Sasaki A, Ueguchi-Tanaka $M$, et al. Loss-of-function of a rice gibberellin biosynthetic gene, GA20 oxidase (GA20ox-2), led to the rice "green revolution". Breed Sci. 2002:52:143-50.

4. Ashikari M, Wu J, Yano M, Sasaki T, Yoshimura A. Rice gibberellin-insensitive dwarf mutant gene Dwarf 1 encodes the alpha-subunit of GTP-binding protein. Proc Natl Acad Sci U S A. 1999;96:10284-9.

5. Börner A. GA response in semidwarf barley. Barley Genet. Newslett. 1996:25:24-7.

6. Caierão E. Effect of induced lodging on grain yield and quality of brewing barley. Crop Breed Appl Biotech. 2006;6:215-21.

7. Chono $\mathrm{M}$, Honda I, Zeniya $\mathrm{H}$, et al. A semidwarf phenotype of barley uzu results from a nucleotide substitution in the gene encoding a putative brassinosteroid receptor. Plant Physiol. 2003;133:1209-19.

8. Dahleen LS, Vander Wal LJ, Franckowiak JD. Characterization and molecular mapping of genes determining semidwarfism in barley. J Hered. 2005:96:654-62.
9. Dockter C, Gruszka D, Braumann I, et al. Induced variations in brassinosteroid genes define barley height and sturdiness, and expand the green revolution genetic toolkit. Plant Physiol. 2014;166:1912-27.

10. Dockter $\mathrm{C}$, Hansson M. Improving barley culm robustness for secured crop yield in a changing climate. J Exp Bot. 2015;66:3499-509.

11. Druka A, Franckowiak J, Lundqvist U, et al. Genetic dissection of barley morphology and development. Plant Physiol. 2011;155:617-27.

12. Foster BP. Mutation genetics of salt tolerance in barley: an assessment of golden promise and other semi-dwarf mutants. Euphytica. 2001;120:317-28.

13. Gustafsson $\AA$, Ekman G. Yield efficiency of the X-ray mutant Svalöf's 'Pallas barley. Züchter/Genet Breed Res. 1967:37:42-6.

14. Honda I, Zeniya H, Yoneyama K, Chono M, Kaneko S, Watanabe Y. Uzu mutation in barley (Hordeum vulgare L.) reduces the leaf unrolling response to brassinolide. Biosci Biotechnol Biochem. 2003;67:1194-7.

15. Hu X, Oian Q, Xu T, et al. The U-box E3 ubiquitin ligase TUD1 functions with a heterotrimeric $\mathrm{G}$ alpha subunit to regulate Brassinosteroid-mediated growth in rice. PLoS Genet. 2013;9:e1003391.

16. Huang X, Qian Q, Liu Z, et al. Natural variation at the DEP1 locus enhances grain yield in rice. Nat Genet. 2009;41:494-7.

17. International Barley Genome Sequencing, C, Mayer KF, Waugh R, et al. A physical, genetic and functional sequence assembly of the barley genome. Nature. 2012:491:711-6.

18. Jia Q, Tan C, Wang J, et al. Marker development using SLAF-seq and wholegenome shotgun strategy to finemap the semi-dwarf gene ari-e in barley. BMC Genomics. 2016;17:911.

19. Johnston CA, Taylor JP, Gao Y, et al. GTPase acceleration as the rate-limiting step in Arabidopsis G protein-coupled sugar signaling. Proc Natl Acad Sci U S A. 2007;104:17317-22.

20. Kucera J, Lundqvist U, Gustafsson A. Induction of breviaristatum mutants in barley. Hereditas. 1975;80:263-78.

21. Li M, Kudrna D, Kleinhofs A. Fine mapping of a semi-dwarf gene brachytic1 in barley. Barley Genet. Newslett. 2001;31:14-7.

22. Mascher M, Gundlach $\mathrm{H}$, Himmelbach A, et al. A chromosome conformation capture ordered sequence of the barley genome: Nature In press; 2017.

23. Peng J, Richards DE, Hartley NM, et al. 'Green revolution' genes encode mutant gibberellin response modulators. Nature. 1999;400:256-61.

24. Powers $L$. The nature of the interactions of genes affecting four quantitative characters in a cross between Hordeum deficiens and vulgare. Genetics. 1936;21:398-420.

25. Rajkumara S. Lodging in cereals. Agricult Rev. 2008;29:55-60.

26. Sashio D, Tanno K, Chono M, Honda I, Kitano H, Tekeda K. Spontaneous brassinolide-insensitive barley mutants "uzu." adapted to East Asia. Breed Sci. 2004;54:409-16.

27. Schulte D, Ariyadasa R, Shi B, et al. BAC library resources for map-based cloning and physical map construction in barley (Hordeum Vulgare L.). BMC Genomics. 2011:12:247.

28. Spielmeyer W, Ellis MH, Chandler PM. Semidwarf (sd-1), "green revolution" rice, contains a defective gibberellin 20-oxidase gene. Proc Natl Acad Sci U S A. 2002;99:9043-8.

29. Stateczny D, Oppenheimer J, Bommert P. G protein signaling in plants: minus times minus equals plus. Curr Opin Plant Biol. 2016;34:127-35.

30. Swenson SP. Genetic and cytological studies on a brachytic mutant in barley. J Agric Res. 1940;60:687-713.

31. Takahashi R. The origin and evolution of cultivated barley. In: Demerec M, editor. Advances in genetics. New York: Academic Press; 1955. p. 227-66.

32. Temple BR, Jones AM. The plant heterotrimeric G-protein complex. Annu Rev Plant Biol. 2007:58:249-66.

33. Tsuchiya T. Allelic relationships of genes for short-awned mutants in barley. Barley Genet Newslett. 1974:4:80-1.

34. Urano D, Chen JG, Botella JR, Jones AM. Heterotrimeric G protein signalling in the plant kingdom. Open Biol. 2013:3:120186.

35. Wendt T, Holme I, Dockter C, et al. HvDep1 is a positive regulator of culm elongation and grain size in barley and impacts yield in an environmentdependent manner. PLoS One. 2016;11:e0168924.

36. Xu Y, Jia Q, Zhou G, et al. Characterization of the sdw1 semi-dwarf gene in barley. BMC Plant Biol. 2017:17:11.

37. Zhang J, Li Z, Zhang C. Analysis of dwarfing genes in Zhepi 1 and Aizao 3 : two dwarfing gene donors in barley breeding in China. Canadian J Plant Sci. 2007;87:93-6.

38. Zhang J, Zhang W. Tracing sources of dwarfing genes in barley breeding in China. Euphytica. 2003;131:285-92. 